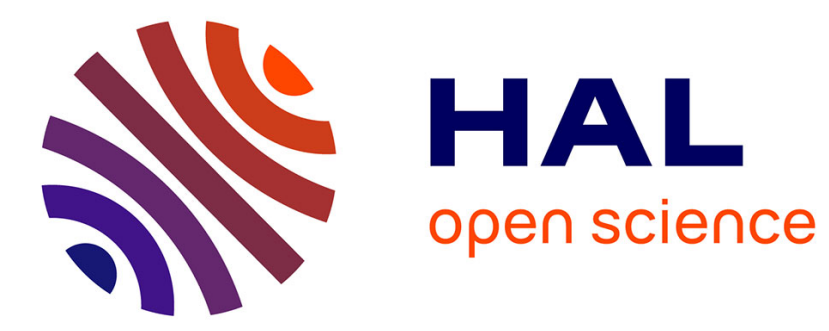

\title{
From metallic cluster-based ceramics to nematic hybrid liquid crystals: a double supramolecular approach.
}

\author{
Susanta K Nayak, Maria Amela-Cortes, Claire Roiland, Stéphane Cordier,
} Yann Molard

\section{- To cite this version:}

Susanta K Nayak, Maria Amela-Cortes, Claire Roiland, Stéphane Cordier, Yann Molard. From metallic cluster-based ceramics to nematic hybrid liquid crystals: a double supramolecular approach.. Chemical Communications, 2015, 51 (18), pp.3774-3777. 10.1039/c4cc10085a . hal-01118509

HAL Id: hal-01118509

https://hal-univ-rennes1.archives-ouvertes.fr/hal-01118509

Submitted on 16 Jun 2015

HAL is a multi-disciplinary open access archive for the deposit and dissemination of scientific research documents, whether they are published or not. The documents may come from teaching and research institutions in France or abroad, or from public or private research centers.
L'archive ouverte pluridisciplinaire HAL, est destinée au dépôt et à la diffusion de documents scientifiques de niveau recherche, publiés ou non, émanant des établissements d'enseignement et de recherche français ou étrangers, des laboratoires publics ou privés. 


\title{
From Metallic Cluster-based Ceramics to Nematic Hybrid Liquid Crystals: A Double Supramolecular Approach
}

\author{
S. K. Nayak, ${ }^{a}$ M. Amela-Cortes,${ }^{a}$ C. Roiland, ${ }^{a}$ S. Cordier,${ }^{a}$ and Y. Molard ${ }^{a, *}$
}

We describe a new supramolecular approach combining hostguest and electrostatic interactions to design hybrid materials containing polyanionic bulky inorganic compounds and showing liquid crystalline properties.

Hybrid organic-inorganic functional materials have become an intense field of research giving rise to a wide range of materials with applications in optic, electronic, biology, photovoltaic or medicine. ${ }^{1}$ Controlling their structuration at the nanometric scale is a major challenge that implies the development of innovative bottom-up approaches. Thus, liquid crystalline (LC) hybrid materials are now in a stage of rapid development. ${ }^{2}$ Indeed, they are easy to process, are able to spontaneously self-assemble over large areas into highly ordered domains and show structural defects self-healing abilities. ${ }^{3}$ Beside advantageous selforganizing properties, segregation phenomena that happen when inorganic and organic components are not interacting should be avoided to get homogeneous and stable materials with high inorganic content. Several strategies have been developed to minimize or suppress phase segregation while integrating bulky inorganic compounds into mesomorphic material, such as silver, ${ }^{4}$ gold $^{5}$ or $\mathrm{ZnO}^{6}$ nanoparticles, ${ }^{7}$ polyoxometallates ${ }^{8}$ or transition metal clusters. ${ }^{9}$ The common approach is the covalent grafting of mesogenic promoters on the surface of inorganic entities. The second way concerns anionic inorganic compounds and consists in the replacement of inorganic counter-cations by functional organic ones bearing LC promoters. ${ }^{10}$ Basing our demonstration on the $\mathrm{Cs}_{2} \mathrm{Mo}_{6} \mathrm{Br}_{14}$ nanometric cluster-based ternary molecular solid state compound, we propose in this work a new, softer and more straightforward strategy to integrate polyanionic inorganic bulky entities in LC materials. Discrete $\left[\mathrm{M}_{6} \mathrm{Q}_{8}{ }_{8} \mathrm{X}_{6}^{\mathrm{a}}\right]^{\mathrm{n}-\mathrm{-}}(\mathrm{Q}=$ chalcogen/halogen, $\mathrm{X}=$ halogen, $\mathrm{M}=\mathrm{Mo}$, Re or $\mathrm{W})$ octahedral transition metal cluster compounds ${ }^{11,12}$ are highly phosphorescent in the red-NIR area. ${ }^{13}$ In particular, $\mathrm{A}_{2}\left[\mathrm{Mo}_{6} \mathrm{Br}^{\mathrm{i}}{ }_{8} \mathrm{Br}^{\mathrm{a}} 6\right]$ salts $(\mathrm{A}=\mathrm{Cs}, \mathrm{Rb}$ or $\mathrm{K})$, obtained by high temperature synthesis, can be further functionalized with organic ligands and/or integrated in hybrid materials. ${ }^{14}$ We use in this work several supramolecular interactions to build the hybrid polymolecular building blocks that will self-assemble: i) hostguest interactions between crown ether (CE) derivatives and alkali cations ${ }^{15}$ and ii) electrostatic interactions between the $\mathrm{CE}$ complex and $\left[\mathrm{Mo}_{6} \mathrm{Br}_{14}\right]^{2-}$ to maintain the poly-ionic supramolecular assembly. Let us stress that combining luminescent lanthanides ions, ${ }^{16}$ transition metals or other ions with mesomorphic or non mesomorphic CE to generate LC materials has already been reported in the literature. It usually leads to well-ordered structures in which new functionalities are provided by metallic cations complexed within the CE cavity. ${ }^{17}$ However, the integration of polyanionic or bulkier inorganic species in LC materials by our indirect method has never been reported so far. To obtain such material, we designed two functional diazacrown ether derivatives, namely $\mathrm{CE}_{3}$ and $\mathrm{CE}_{9}$ as depicted in Scheme 1. These organic compounds are made of six cyanobiphenyl (CB) units, a well-known liquid crystalline promoter, linked to the diazacrown via alkyloxy chains connected to a benzoic core. Using a short or long spacer between the mesogenic units and the complexing center modify the coupling between both motion moieties which should influence the self-assembling process.

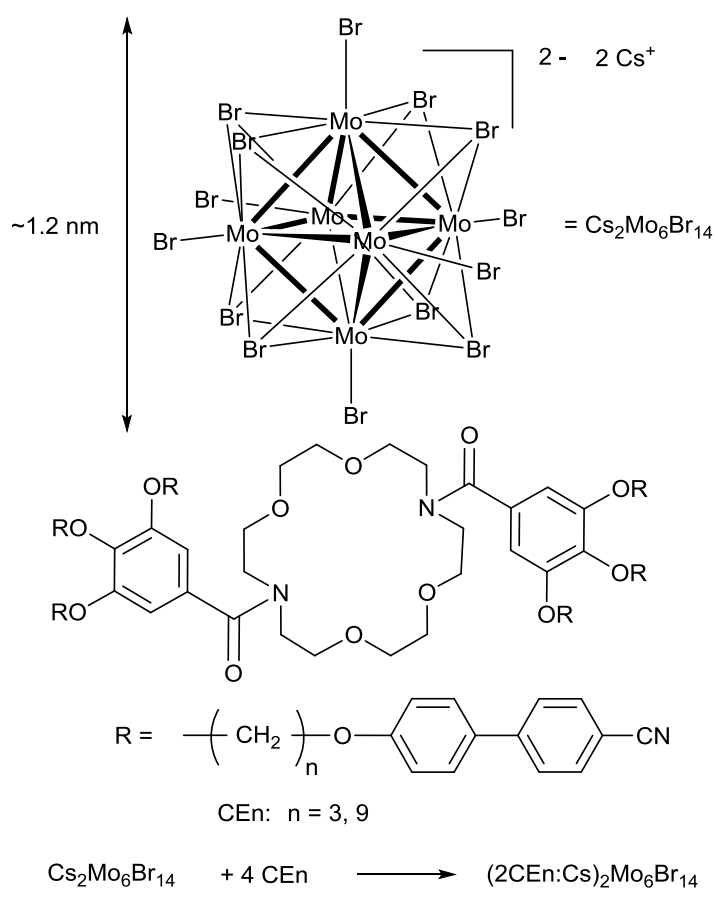

Scheme 1. Schematic representation of diazacrownether derivatives and complexes synthesized in this study.

$\mathrm{CE}_{\mathrm{n}}$ were characterized by the usual techniques such as ${ }^{1} \mathrm{H}$ and ${ }^{13} \mathrm{C}$ NMR, mass spectrometry and elemental analysis (see ESI for 
experimental details). $\mathrm{Cs}_{2} \mathrm{Mo}_{6} \mathrm{Br}_{14}$ salt was obtained by high temperature solid state synthesis using reported procedure with conform analytical data. ${ }^{11}$ The synthesis of hybrids was achieved by mixing in solution the cluster salt with $\mathrm{CE}_{\mathrm{n}}$ in a $1: 4$ ratio in order to fully complex $\mathrm{Cs}^{+}$cations. Indeed, it is well known that 2:1 sandwich or 3:2 club sandwich topologies are usually observed in this type of complexes. ${ }^{18}$ In our case, using lower cluster: $\mathrm{CE}_{n}$ ratio than 1:4 lead to non-homogeneous mixtures with phase segregation that was easily identified by polarized optical microscopy (POM) under UV irradiation (see ESI Fig S1 and S2). 400MHz ${ }^{1} \mathrm{H}$ NMR spectra recorded in solution for the complexes are nearly identical to their parent $\mathrm{CE}_{\mathrm{n}}{ }^{1} \mathrm{H} \mathrm{NMR}$ spectra (see ESI Figure S3 and S4). This can be explained by the low binding affinity in solution of $\mathrm{Cs}^{+}$for diazacrown-[6]-ether derivatives ${ }^{19}$ which implies the introduction of a large excess of guest to observe noticeable variations in the ${ }^{1} \mathrm{H}$ NMR spectrum of the host. ${ }^{20}$ Indeed, the size of our macrocycle cavity is more suitable for $\mathrm{K}^{+}$cation and only few works describe mesomorphic material containing 18C6 CE:Cs complexes. ${ }^{21,} 22$ Nonetheless, ${ }^{79} \mathrm{Br}$ and ${ }^{133} \mathrm{Cs}$ MAS solid state $600 \mathrm{MHz}$ NMR experiments performed on $\mathrm{Cs}_{2} \mathrm{Mo}_{6} \mathrm{Br}_{14}$ and both complexes either at $25^{\circ} \mathrm{C}$ or in the $\mathrm{LC}$ phase at $50^{\circ} \mathrm{C}$ for $\left(2 \mathrm{CE}_{9}: \mathrm{Cs}\right)_{2} \mathrm{Mo}_{6} \mathrm{Br}_{14}$ confirm the complexes formation (Figure 1).

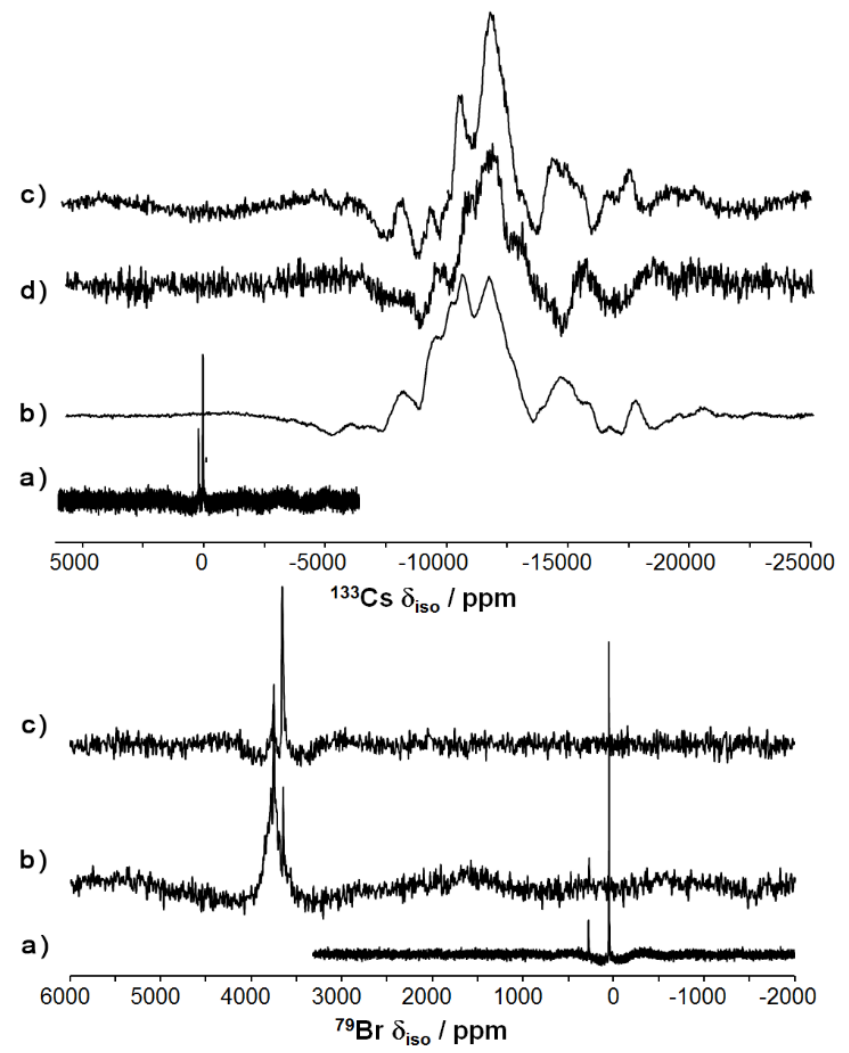

Figure 1. $150 \mathrm{MHz}{ }^{133} \mathrm{Cs}$ (top) and $78 \mathrm{MHz}{ }^{79} \mathrm{Br}$ (bottom) MAS NMR spectra of a) $\mathrm{Cs}_{2} \mathrm{Mo}_{6} \mathrm{Br}_{14}$, b) $\left(2 \mathrm{CE}_{3}: \mathrm{Cs}\right)_{2} \mathrm{Mo}_{6} \mathrm{Br}_{14}$, c) and d) $\left(2 \mathrm{CE}_{9}: \mathrm{Cs}\right)_{2} \mathrm{Mo}_{6} \mathrm{Br}_{14}$ at $25^{\circ} \mathrm{C}$ and $50^{\circ} \mathrm{C}$ respectively.

While two sharp singlets located at $36.7 \mathrm{ppm}$ and $216 \mathrm{ppm}$ are observed in the ${ }^{133} \mathrm{Cs}$ spectrum of $\mathrm{Cs}_{2} \mathrm{Mo}_{6} \mathrm{Br}_{14}$ (within the $\mathrm{Cs}_{2} \mathrm{Mo}_{6} \mathrm{Br}_{14}$ crystal structure, $\mathrm{Cs}^{+}$location is shared between two crystallographic positions and interacts with inner and apical $\mathrm{Br}$ ligands), ${ }^{11}$ only one very broad (due to the non-crystallinity of the complex) and strongly shielded signal is observed in the complexes.

Although these signals are particularly large, their position and structuration are very similar for both complexes indicating that $\mathrm{Cs}^{+}$cations are surrounded by the same environment. Their strong shielding reflects an enhancement of the $\mathrm{Cs}^{+}$electronic density that is attributed to their interactions with the free electronic doublets of the macrocycle oxygen atoms. On the other hand, ${ }^{79} \mathrm{Br}$ NMR spectra are constituted by two singlets located at $51 \mathrm{ppm}$ and $278 \mathrm{ppm}$ for $\mathrm{Cs}_{2} \mathrm{Mo}_{6} \mathrm{Br}_{14}$ that are broadened and drastically shifted to $3652 \mathrm{ppm}$ and $3762 \mathrm{ppm}$ for (2CE9:Cs) ${ }_{2} \mathrm{Mo}_{6} \mathrm{Br}_{14}$ and $3654 \mathrm{ppm}$ and $3757 \mathrm{ppm}$ for $\left(2 \mathrm{CE}_{3}: \mathrm{Cs}\right)_{2} \mathrm{Mo}_{6} \mathrm{Br}_{14}$. These strong shifts indicate also that the electronic environment of the cluster anion is drastically modified and that there is no $\mathrm{Cs}-\mathrm{Br}$ direct interactions within the complex.

Although, the binding affinity of $\mathrm{Cs}^{+}$for $\mathrm{CE}_{\mathrm{n}}$ ligands might appear low, complexes remain very stable either under thermal treatment above their isotropization temperature (Fig S1 and S2) or after ageing for several months (no segregation observed in both cases). To give another proof that, the $\mathrm{CE}$ center is responsible of the homogeneity and stability of these materials and that they are not simple clusters-LC dispersion, we mixed $\mathrm{Cs}_{2} \mathrm{Mo}_{6} \mathrm{Br}_{14}$ with the commercial 5OCB (4'-(Pentyloxy)-4Biphenyl Carbonitrile) LC. As expected, we observed a full segregation of clusters within the nematic host (Fig S5).

The mesomorphic properties of $\mathrm{CE}_{n}$ and their respective complex with $\mathrm{Cs}_{2} \mathrm{Mo}_{6} \mathrm{Br}_{14}$ were studied by differential scanning calorimetry (DSC), Polarized optical microscopy (POM) and temperature variable small angle $x$-ray scattering (SAXS). Table 1 gathers the observed phase transition temperatures and thermodynamic data.

Table 1. Phase behaviour, transition temperatures and melting enthalpies of CE derivatives and their respective complexes taken from the 2 nd heating.

\begin{tabular}{cccccc}
\hline Compound & Transition & $\begin{array}{c}\mathrm{T} \\
{\left[{ }^{\circ} \mathrm{C}\right]}\end{array}$ & $\Delta \mathrm{Cp}^{\mathrm{b})}$ & $\Delta \mathrm{H}^{\mathrm{c})}$ & $\Delta \mathrm{H} / \mathrm{nb}_{\mathrm{CB}}{ }^{\mathrm{c})}$ \\
\hline $\mathrm{CE}_{9}$ & $\mathrm{~g} \rightarrow \mathrm{N}$ & 30.6 & 1.19 & - & - \\
& $\mathrm{N} \rightarrow \mathrm{I}$ & 86.2 & - & 7.60 & 1.27 \\
\hline $\mathrm{CE}_{3}$ & $\mathrm{~g} \rightarrow \mathrm{N}$ & 70.6 & 1.43 & - & \\
& $\mathrm{N} \rightarrow \mathrm{I}$ & $102^{\mathrm{a})}$ & - & - & \\
\hline$\left(2 \mathrm{CE}_{9}: \mathrm{Cs}\right)_{2} \mathrm{Mo}_{6} \mathrm{Br}_{14}$ & $\mathrm{~g} \rightarrow \mathrm{N}$ & 37.4 & 0.45 & - & - \\
& $\mathrm{N} \rightarrow \mathrm{I}$ & 83.9 & & 27.51 & 1.15 \\
\hline$\left(2 \mathrm{CE}_{3}: \mathrm{Cs}\right)_{2} \mathrm{Mo}_{6} \mathrm{Br}_{14}$ & $\mathrm{~g} \rightarrow \mathrm{N}$ & 76.1 & 1.14 & - & \\
& $\mathrm{N} \rightarrow \mathrm{I}$ & $113^{\mathrm{a})}$ & - & - & \\
& & & & &
\end{tabular}

a) Temperature determined by microscopy; b) in $\mathrm{KJ}$ mol-1K-1; c) in $\mathrm{KJ}$ mol-1; g: glass, N: nematic, I:isotropic.

All samples underwent three heating/cooling cycles to record DSC thermograms (see ESI Figure S6-S9). $\mathrm{CE}_{3}$ and $\mathrm{CE}_{9}$ show enantiotropic LC behaviour followed on cooling, by a glass transition. For $\mathrm{CE}_{3}$ and its complex, the $\mathrm{LC}$ to I transition could not be detected by DSC. Therefore, the phase transition temperature reported is that observed by microscopy. It increases by $10^{\circ} \mathrm{C}$ for the complex compared to $\mathrm{CE}_{3}$ which is commonly 
ascribed to the complexation induced rigidification of the polymolecular system. ${ }^{23}$ For $\mathrm{CE}_{9}$ and its complex, the LC to I transition temperatures do not differ significantly. Although it might only be a coincidence, it could be imparted to the facts that i) the long alkoxy chains prevent strong interactions between the $\mathrm{CE}$, the cations and the anionic clusters ${ }^{24}$ and ii) $\mathrm{Cs}^{+}$is too bulky to perfectly fit in the $18 \mathrm{C} 6 \mathrm{CE}$ cavity. Indeed, it is also usually recognized that the stability of the induced mesophase depends strongly on the size of the cation. ${ }^{21}$ These points are corroborated by the calculated enthalpy values per mesogenic unit that are very similar and in the range of those observed for $\mathrm{N}$ to $\mathrm{I}$ transitions. ${ }^{25}$

POM micrographs obtained in the LC phase for ligands and complexes are presented in Figure 2. While $\mathrm{CE}_{9}$ and its complex show a typical nematic texture under white light, it was not possible to observe a very clear texture for $\left(2 \mathrm{CE}_{3}: \mathrm{Cs}\right)_{2} \mathrm{Mo}_{6} \mathrm{Br}_{14}$ probably because of its high viscosity. In this last case, molecules were homeotropically aligned and a vanishing birefringence was observed only on shearing. SAXS experiments carried out between $90^{\circ} \mathrm{C}$ and $20^{\circ} \mathrm{C}$ are in good accordance with the nematic nature of all samples (see ESI Figures S10-S11 for temperature dependent diffractograms studies). It is well known that LC crown ether derivatives are usually well organized within the mesophase because of segregation phenomena between aromatic, polyether and aliphatic fragments leading to cubic, columnar or lamellar phases. ${ }^{26}$ These phenomena should be more pronounced for $\mathrm{CE}_{9}$ derivatives than for $\mathrm{CE}_{3}$ because the long alkoxy chains allow a better decoupling between the motion of complexing centers and CB units. Generally, the introduction of alkali salts induces the formation of more ordered phases or can generate mesomorphism from non mesomorphic compounds. ${ }^{23}$, 27 Consequently, nematogenic CE, CE:alkali or CE:transition metal complexes are quite rare. ${ }^{23,} 24,28$ In our case, the two complexes self-assemble in different ways as only (2 $\left.\mathrm{CE}_{9}: \mathrm{Cs}\right)_{2} \mathrm{Mo}_{6} \mathrm{Br}_{14}$ diffractograms present a small and relatively sharp scattering reflection at $4.1 \AA$ that could correspond to the CE-CE distance in the sandwich complex and that may be indicative of a nematic columnar phase. ${ }^{29}$

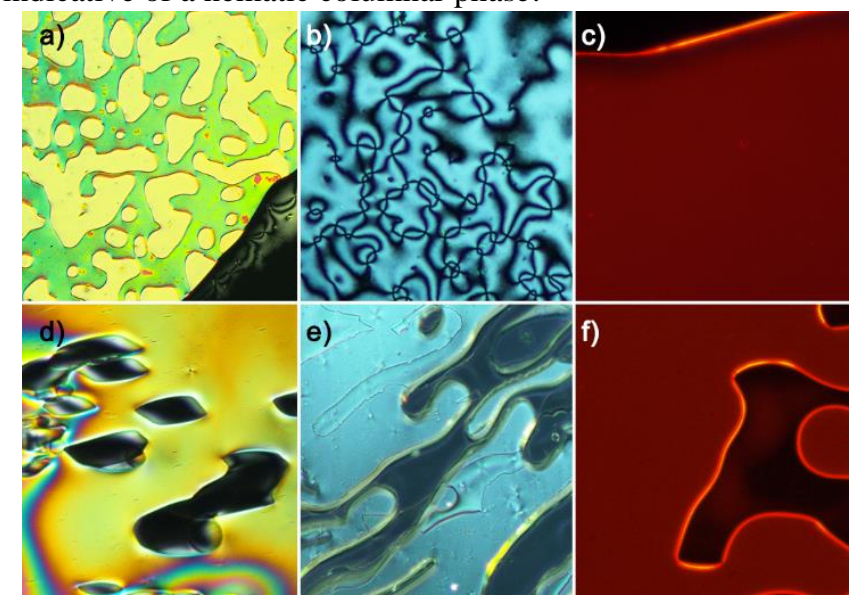

Figure 2. Polarized optical micrographs obtained for a) CE9 $\left(45^{\circ} \mathrm{C}\right)$, b) and c) (2CE9:Cs) $2 \mathrm{Mo6Br} 14\left(80^{\circ} \mathrm{C}\right.$, b) white light, c) UV irradiation), d) $\mathrm{CE} 3\left(80^{\circ} \mathrm{C}\right)$, e) and f) $(2 \mathrm{CE} 3: \mathrm{Cs}) 2 \mathrm{Mo} 6 \mathrm{Br} 14\left(85^{\circ} \mathrm{C}\right.$, e) white light, f) UV irradiation).
UV Irradiation $\left(\lambda_{\text {exc }}=380 \mathrm{~nm}\right)$ of complexes in the LC phase leads to a homogeneous deep red emission characteristic of transition metal clusters that evidences the homogeneity of the material.

Absolute quantum yields were measured at $25^{\circ} \mathrm{C}$ using an integrating sphere on glassy samples and compared to the parent cluster in its powdered form. Calculated values $(0.21$ for (2 $\left.\mathrm{CE}_{3}: \mathrm{Cs}\right)_{2} \mathrm{Mo}_{6} \mathrm{Br}_{14}, \quad 0.15$ for $\left(2 \mathrm{CE}_{9}: \mathrm{Cs}\right)_{2} \mathrm{Mo}_{6} \mathrm{Br}_{14}, 0.14$ for $\mathrm{Cs}_{2} \mathrm{Mo}_{6} \mathrm{Br}_{14}$ at $\lambda_{\text {exc }}=380 \mathrm{~nm}$ ) are in the same range and show that the luminescence properties of the metallic cluster core are not altered either qualitatively or quantitatively by their introduction in the LC material (see ESI Figure S12-S14 for photoluminescence spectra).

\section{Conclusions}

In conclusion, we describe in this work, a new and straightforward approach to develop new hybrid materials merging the functionalities of nanometric inorganic anionic entities with the self-assembling abilities of organic liquid crystals. Our strategy combines host guest complex formation between $\mathrm{Cs}^{+}$cations and diazacrown derivatives, with electrostatic interactions that maintain the functional inorganic anion within the material in close vicinity with the macrocycles. Homogeneous materials are obtained by simple mixing in solution of inorganic salts and organic ligands in the right proportions. By applying this innovative strategy to the ternary $\mathrm{Cs}_{2} \mathrm{Mo}_{6} \mathrm{Br}_{14}$ solid state compound, we were able to generate a new hybrid material in which the bulky inorganic transition metal cluster keeps its luminescence properties, and remarkably, which possesses a nematic behaviour on broad temperature ranges. We must stress that these nanomaterials constitute the first example of poly-ionic nematic liquid crystal and we expect that our method can be generalized to other type of inorganic poly-anionic entities whose charge is counter-balanced by alkali or ammonium cations such as clusters with other nuclearity or polyoxometallates often obtained as alkali or ammonium salts.

\section{Acknowledgements}

This work was supported by a Marie Curie International Incoming Fellowship within the 7th European Community Framework Program, by Fondation Langlois, and ANR Clustomesogen ANR-13-BS07-0003-01. We thank Dr. F. Artzner and C. Meriadec for SAXS measurements.

\section{Notes and references}

${ }^{a}$ Université de Rennes 1 - CNRS UMR 6226 "Institut des Sciences Chimiques de Rennes", Campus de Beaulieu, CS 74205, 35042 Rennes Cedex, France

E-mail: yann.molard@univ-rennes1.fr

Electronic Supplementary Information (ESI) available: Experimental details, POM micrographs, NMR spectra, DSC thermograms, SAXS diffractograms, luminescence spectra, molecular model of $2 \mathrm{CE}_{3}: \mathrm{Cs}$. See DOI: $10.1039 / \mathrm{c} 000000 \mathrm{x} /$

C. Sanchez, P. Belleville, M. Popall and L. Nicole, Chem. Soc. Rev., 2011, 40, 696. 
O. Stamatoiu, J. Mirzaei, X. Feng and T. Hegmann, Top. Curr. Chem., 2012, 318, 331; H. K. Bisoyi and S. Kumar, Chem. Soc. Rev., 2011, 40, 306.

3. C. Tschierske, Angew. Chem. Int. Ed. Engl., 2013, 52, 8828.

4. W. Lewandowski, D. Constantin, K. Walicka, D. Pociecha, J. Mieczkowski and E. Gorecka, Chem. Commun., 2013, 49, 7845 .

5. C. H. Yu, C. P. J. Schubert, C. Welch, B. J. Tang, M. G. Tamba and G. H. Mehl, J. Am. Chem. Soc., 2012, 134, 5076; L. Cseh and G. H. Mehl, J. Am. Chem. Soc., 2006, 128, 13376.

6. C. Neaime, M. Prévôt, M. Amela-Cortes, V. Cîrcu, F. Grasset, H. Folliot and Y. Molard, Chem. Eur. J., 2014, 20, 17770; S. Saliba, Y. Coppel, P. Davidson, C. Mingotaud, B. Chaudret, M. L. Kahn and J.-D. Marty, J. Mater. Chem., 2011, 21, 6821.

7. G. L. Nealon, R. Greget, C. Dominguez, Z. T. Nagy, D. Guillon, J.-L. Gallani and B. Donnio, Beilstein J. Org. Chem., $2012,8,349$.

8. E. Terazzi, G. Rogez, J.-L. Gallani and B. Donnio, J. Am Chem. Soc., 2013, 135, 2708; B. Li, J. Zhang, S. Wang, W. Li and L. Wu, Eur. J. Inorg. Chem., 2013, 2013, 1869; G. Rogez, B. Donnio, E. Terazzi, J. L. Gallani, J. P. Kappler, J. P. Bucher and M. Drillon, Adv. Mater., 2009, 21, 4323; W. Li, S. Y. Yi, Y. Q. Wu and L. X. Wu, J. Phys. Chem. B, 2006, 110, 16961. M. Amela-Cortes, F. Dorson, M. Prévôt, A. Ghoufi, B. Fontaine, F. Goujon, R. Gautier, V. Cîrcu, C. Mériadec, F. Artzner, H. Folliot, S. Cordier and Y. Molard, Chem. Eur. J., 2014, 20, 8561; M. Amela-Cortes, S. Cordier, N. G. Naumov, C. Meriadec, F. Artzner and Y. Molard, J. Mater. Chem. C, 2014, 2, 9813; Y. Molard, A. Ledneva, M. Amela-Cortes, V. Circu, N. G. Naumov, C. Meriadec, F. Artzner and S. Cordier, Chem. Mater., 2011, 23, 5122; A. S. Mocanu, M. AmelaCortes, Y. Molard, V. Circu and S. Cordier, Chem. Commun., 2011, 47, 2056; Y. Molard, F. Dorson, V. Circu, T. Roisnel, F. Artzner and S. Cordier, Angew. Chem. Int. Ed. Engl., 2010, 49, 3351.

10. C. F. J. Faul and M. Antonietti, Adv. Mater., 2003, 15, 673.

11. K. Kirakci, S. Cordier and C. Perrin, Z. Anorg. Allg. Chem., 2005, 631, 411.

12. J. R. Long, L. S. McCarty and R. H. Holm, J. Am. Chem. Soc., 1996, 118, 4603

13. M. N. Sokolov, M. A. Mihailov, E. V. Peresypkina, K. A Brylev, N. Kitamura and V. P. Fedin, Dalton Trans., 2011, 40, 6375; A. W. Maverick, J. S. Najdzionek, D. MacKenzie, D. G. Nocera and H. B. Gray, J. Am. Chem. Soc., 1983, 105, 1878.

14. S. Cordier, Y. Molard, K. A. Brylev, Y. V. Mironov, F. Grasset, B. Fabre and N. G. Naumov, J. Cluster Sci., 2014, doi:10.1007/s10876; M. Amela-Cortes, A. Garreau, S. Cordier, E. Faulques, J.-L. Duvail and Y. Molard, J. Mater. Chem. C, 2014, 2, 1545; Y. Molard, C. Labbe, J. Cardin and S. Cordier, Adv. Funct. Mater., 2013, 23, 4821; A. Garreau, F. Massuyeau, S. Cordier, Y. Molard, E. Gautron, P. Bertoncini, E. Faulques, J. Wery, B. Humbert, A. Bulou and J. L. Duvail, Acs Nano, 2013, 7, 2977; G. Prabusankar, Y. Molard, S. Cordier, S. Golhen, Y. Le Gal, C. Perrin, L. Ouahab, S. Kahlal and J. F. Halet, Eur. J. Inorg. Chem., 2009, 2153; B. Fabre, S. Cordier, Y. Molard, C. Perrin, S. Ababou-Girard and C. Godet, J. Phys. Chem. C, 2009, 113, 17437; S. Cordier, F. Dorson, F. Grasset, Y. Molard, B. Fabre, H. Haneda, T. Sasaki, M. Mortier, S. Ababou-Girard and C. Perrin, J. Clust. Sci., 2009, 20, 9; F. Grasset, Y. Molard, S. Cordier, F. Dorson, M. Mortier, C. Perrin, M. Guilloux-Viry, T. Sasaki and H. Haneda, Adv. Mater., 2008, 20, 1710; F. Grasset, F. Dorson, S. Cordier, Y. Molard, C. Perrin, A.-M. Marie, T. Sasaki, H. Haneda, Y. Bando and M. Mortier, Adv. Mater., 2008, 20, 143; S. Ababou-Girard, S. Cordier, B. Fabre, Y. Molard and C. Perrin, ChemPhysChem, 2007, 8, 2086.

15. R. M. Izatt, K. Pawlak, J. S. Bradshaw and R. L. Bruening, Chem. Rev., 1995, 95, 2529; J. M. Lehn, Angew. Chem. Int Ed. Engl., 1988, 27, 89; D. J. Cram, Science, 1988, 240, 760; C. J. Pedersen, J. Am. Chem. Soc., 1970, 92, 386.

16. S. Suarez, O. Mamula, R. Scopelliti, B. Donnio, D. Guillon, E. Terazzi, C. Piguet and J.-C. G. Buenzli, New J. Chem., 2005, 29, 1323.
17. M. Kaller and S. Laschat, Top. Curr. Chem., 2012, 318, 109; F. Neve, Adv. Mater., 1996, 8, 277.

18. J. W. Steed, Coord. Chem. Rev., 2001, 215, 171; K. V. Domasevitch, J. A. Rusanova, O. Y. Vassilyeva, V. N. Kokozay, P. J. Squattrito, J. Sieler and P. R. Raithby, J. Chem. Soc., Dalton Trans., 1999, 3087; R. H. Huang, J. L. Eglin, S. Z. Huang, L. E. H. McMills and J. L. Dye, J. Am. Chem. Soc., 1993, 115, 9542; J. L. Dye and M. G. DeBacker, Annu. Rev. Phys. Chem., 1987, 38, 271; J. L. Vidal, R. C. Schoening and J. M. Troup, Inorg. Chem., 1981, 20, 227.

19. N. G. Luk'yanenko, S. S. Basok, E. Y. Kulygina and V. I. Vetrogon, Russ. J. Gen. Chem., 2003, 73, 1919; H. J. Buschmann, E. Cleve and E. Schollmeyer, J. Solution Chem., 1994, 23, 569; H. J. Buschmann, Inorg. Chim. Acta, 1986, 120, 125; M. Shamsipur and A. I. Popov, Inorg. Chim. Acta, 1980, 43, 243.

20. Y. Molard, D. M. Bassani, J.-P. Desvergne, N. Moran and J. H. R. Tucker, J. Org. Chem., 2006, 71, 8523; Y. Molard, D. M. Bassani, J.-P. Desvergne, P. N. Horton, M. B. Hursthouse and J. H. R. Tucker, Angew. Chem., Int. Ed., 2005, 44, 1072.

21. J. A. Schröter, C. Tschierske, M. Wittenberg and J. H. Wendorff, Angew. Chem. Int. Ed., 1997, 36, 1119.

22. S. Shinkai, T. Nishi, A. Ikeda, T. Matsuda, K. Shimamoto and O. Manabe, J. Chem. Soc. Chem. Commun., 1990, 303.

23. J. W. Goodby, G. H. Mehl, I. M. Saez, R. P. Tuffin, G. Mackenzie, R. Auzely-Velty, T. Benvegnu and D. Plusquellec, Chem. Commun., 1998, 2057.

24. K. Leblanc, P. Berdague, J. P. Bayle, P. Judeinstein and J. Rault, Chem. Commun., 2000, 1291.

25. S. Singh, Physics Reports-Review Section of Physics Letters, 2000, 324, 108.

$26 . \quad$ V. Percec, W.-D. Cho, G. Ungar and D. J. P. Yeardley, Chem. Eur. J., 2002, 8, 2011.

27. G. Johansson, V. Percec, G. Ungar and D. Abramic, J. Chem. Soc., Perkin Trans. 1, 1994, 447.

$28 . \quad$ R. P. Tuffin, K. J. Toyne and J. W. Goodby, J. Mater. Chem., 1995, 5, 2093.

29 G. Pilet, S. Cordier, C. Perrin and A. Perrin, Inorg. Chim. Acta, 2003, 350, 537. 